\title{
METAFORA MAKNAWI DAN UNIVERSALITAS BAHASA ALQURAN: STUDI LINGUISTIK BAHASA ARAB
}

\author{
Harun Al-Rasyid \\ Universitas Islam Negeri Sumatera Utara \\ alrasyid39@gmail.com
}

\begin{abstract}
Among the features of the miracles of the Qur'an is on its perfection of language and meaning that includes in the study of linguistics (al-durus min jibhat al-lughah). The linguistics can be seen, for example, from the aspect of style, the broad meaning of words and sentences that have meanings beyond their literal significance. One of the literary styles of the Qur'an that often used is the metaphors (isti'arah) which is an integral part of the study of al-majaz al-lughawi. Many scholars argue that this metaphorical aspect of the Qur'an closely related to the function of beautifying word structure. On the other hand, this article aims to show that the metaphorical aspect of the Qur'an has several strategic functions, including to build and expand an idea that was previously unthinkable and to broaden the idea of a living order comprehensively. By discussing linguistic studies from the aspect of majari (metaphor) and the elaboration of the meaning of the word (altaghayyur al-dala'il) in the Qur'an, this article, therefore, confirms the universality and flexibility of the Qur'anic language.
\end{abstract}

Key words: Ma'nawi, the language of the Koran, Metaphor, Balaghah.

Abstrak: Salah satu keistimewaan yang merupakan bagian dari kemukjizatan Alquran adalah kesempurnaan bahasa dan keluasan makna yang tergolong dalam kajian kebahasaan (al-durüs min jübhat al-lughah). Sisi linguistik tersebut dapat ditilik dari aspek gaya bahasa, perluasan makna kata dan kalimat yang memiliki pengertian di luar makna sesungguhnya. Salah satu gaya literer Alquran yang sering dipakai adalah penggunaan metafora (isti arah) yang merupakan bagian tak terpisahkan dari kajian almajaz al-lughawi. Banyak yang berpandangan bahwa aspek metaforis Alquran ini terkait erat dengan fungsi untuk memperindah susunan kata. Sebaliknya, artikel ini ingin menunjukan bahwa aspek metaforis Alquran memiliki beberapa fungsi strategis, di antaranya: untuk membangun dan memperluas sebuah gagasan yang sebelumnya tidak terfikirkan dan untuk meluaskan gagasan tata kehidupan secara komprehenshif. Dengan membahas kajian kebahasaan dari aspek maja $\bar{i}$ (metafora) dan perluasan makna kata (al-taghayyur al-dala'il) dalam Alquran, artikel ini hendak mengkonfirmasi keuniversalan dan fleksibilitas bahasa Alquran.

Kata kunci: Ma'nawi, Bahasa Alquran, Metafora, Balagah. 


\section{Pendahuluan}

Alquran sebagai sumber utama dari berbagai produk hukum, politik, sosial dan budaya dalam tatanan kehidupan umat Islam harus dipahami juga sebagai petunjuk dari Allah bagi umat dengan visi memperbaiki segala lini sosial-teologis. Di samping fungsi strategis itu, Alquran juga memiliki keunggulan dalam struktur bahasa dan keindahan makna. Menurut Arkoun, Alquran merupakan korpus terbuka bagi berbagai kemungkinan makna. Dengan demikian, ayat Alquran selalu terbuka untuk interpretasi baru, tidak pernah tertutup dalam interpretasi tunggal. Senada dengan itu, Ali Harb memberikan penegasan akan kesempurnaan yang terdapat dalam makna Alquran, seperti yang ditegaskan dalam karangannya al-Ta'wīl, bahwa Alquran amat kaya dengan makna dan tidak hanya sering menggunakan bahasa langsung dalam arti satu lafal satu makna, melainkan bahasa tak langsung yakni dengan bahasa metafora. Metafora tidak hanya berfungsi sebgai penghias bahasa, namun membawa gagasan akidahibadah dan tata kehidupan manusia. ${ }^{1}$

Para pengkaji Alquran menganggap sisi sastra Alquran sebagai, meminjam istilah Nur Kholis, absolute beauty. ${ }^{2}$ Anggapan kulminasi tersebut membawa konsekuensi logis: jamak tafsir yang berorientasi menyingkap sisi sastrawi Alquran. Paradigma demikian menempatkan pembuktian ijā bahasa Alquran bukan hanya berlaku pada dataran dogmatis, ia bisa dikaji dan dibuktikan secara empiris. Salah satu aspek balagah Alquran adalah metafora, yang belakangan menempati bab tashbīb dalam literatur balagah. Menarik digarisbawahi bahwa metafora termasuk perangkat literer yang penting dalam tradisi sastra, baik Alquran maupun teks lain. Kecakapan bermetafora menunjukkan pengarang memiliki logika cemerlang, karena posisi metafora seringkali ditujukan untuk membuat analogi yang presisi antar dua hal yang diserupakan.

Berangkat dari fenomena di atas, maka perlu kiranya mengetengahkan pembahasan tentang gaya ungkap Alquran terkait metafora untuk menampilkan bentuk sastrawi tinggi. Artikel ini akan membahas metafora Alquran dan hubungannya dengan sisi universalitas gaya bahasa Alquran.

1 'A $\bar{i}$ Harb, Al-Ta'wìl wa al-Haqiqah (Beirut: Dār al-Tanwir, 1995), 26.

2 M. Nur Kholis Setiawan, Al-Qur'an Kitab Sastra Terbesar (Yogyakarta: eLSAQ Press, 2005), 2. 


\section{Akar Historis Bahasa Arab dan Keunggulannya}

Bahasa Arab yang merupakan salah satu alat komunikasi manusia untuk menyampaikan gagasan, memiliki sejarah kemunculannya. Munculnya suatu bahasa ditengah-tengah masyarakat tanpa melalui proses musyawarah, akan tetapi lahirnya suatu bahasa adalah dengan kesepakatan untuk berkomunikasi di antara meraka. Ungkapan ini senada dengan apa yang didefinisikan oleh Ibn Khaldūn yang mengatakan bahwa bahasa adalah "Ungkapan seorang pembicara akan maksud-maksudnya."3 Sedangkan al-Ghulayayn mengatakan, "Bahasa adalah kata-kata yang digunakan oleh sekelompok kaum untuk mengungkapkan maksud-maksudnya." ${ }^{4}$ Dari sinilah lahir beragam dan jenis bahasa untuk dapat digunakan oleh kalangan mereka menyampaikan keinginannya.

Para ahli liguistik mengelompokkan bahasa Arab ke dalam rumpun bahasa Semit yang menjadi salah satu rumpun dari bahasa semit-hemit, atau dalam bahasa Arab di sebut dengan al-Hamiyah alSamiyah. ${ }^{5}$ Ditinjau dari klasifikasi kemunculannya, para ahli membagi bahasa dengan menyatakan bahwa induk bahasa adalah Bahasa Samiyah (Semit); mencakup bahasa Arab, Ibrani, Sumeria, Kaldea, Habsyi (Ethiopia), Assyria, Babilonia, Punisia, Hamiri, dan Nabthea. Kemudian disusul Bahasa Ariya; mencakup bahasa Hindu kuno, Sansekerta (termasuk turunannya adalah: bahasa Persia Kuno, bahasa Latin dan Jerman), dan derivatnya yang merupakan bahasa modern,

3 Abū Zayd 'Abd al-Raḥmān b. Muḥammad b. Khaldūn, Terjemah Muqoddimah Ibnu Kholdun, terj. Ahmadie Thoha (Jakarta: Pustaka Firdaus, 1986), 776. Lebih lanjut WJS Poerwadarminta menyatakan, "Bahasa adalah sistem lambang yang dipakai orang untuk melahirkan pikiran dan perasaan. Lihat WJS Poerwadarminta, Kamus Umum Bahasa Indonesia (Jakarta: Balai Pustaka, 1991), 75.

${ }^{4}$ Dari pendapat ini ia menjelaskan bahwa bahasa Arab adalah:

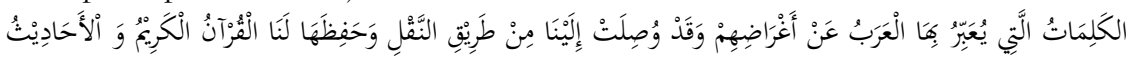

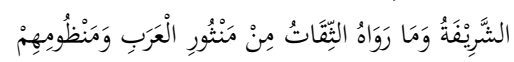

'Berbagai kata yang digunakan orang-orang Arab untuk mengungkapkan berbagai maksud atau tujuan mereka, disampaikan pada kita dengan jalan menukil/ transfer/ riwayat, dihimpun dan dijaga kepada kita oleh al-Quran al-Karim dan hadits-hadits mulia, dan berbagai riwayat terpercaya berupa prosa-prosa dan syair-syair Arab." Lihat Mustafa al-Ghulayayn, Jamī' al-Durus al-'Arabiyah, vol 1 (Beirūt: al-Maktabat al'Așriyah li al-Tibā'ah wa al-Tawzi', 1989), 7.

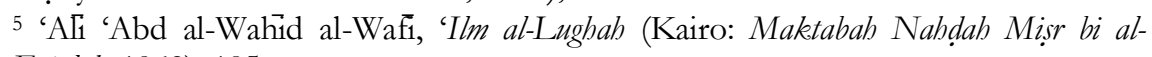
Fajalah, 1962), 185. 
yaitu bahasa Inggris, Jerman, Prancis, Italia, dan Spanyol. Terakhir, Bahasa Turani (Mesir kuno); Turki, Hongaria, Tartar, dan Mongolia. ${ }^{6}$

Menurut ahli sejarah Jerman August Ludwig Schlozer bahasa Semit adalah kumpulan bahasa-bahasa yang muncul sejak lama di kawasan Asia dan Afrika, sementara sebagian lagi telah punah seiring berjalannya waktu. Bahasa Semit masih digunakan oleh jutaan orang yang berada di kedua kawasan tersebut karena memiliki kekayaan budaya dan sastra tersendiri. ${ }^{7}$ Para sejarawan dan ahli bahasa bersepakat bahwa bahasa Arab termasuk salah satu dari rumpun bahasa Semit, yang meliputi bahasa-bahasa Babilonia, Asyuria, Aramy, Ibrani, Yaman Lama, Habsyi Semit dan bahasa Arab itu sendiri. Maka tidak mengherankan jika beberapa tokoh mengungkapkan beberapa kata dalam Alquran itu berasal atau menyerap bahasa lain, seperti jizyah, kata ini menurut Rashìd Rị̣ā, sebagaimana dikutip Mun'im Sirry, kemungkinan berasal dari bahasa Persia. ${ }^{8}$

Dari beberapa rumpun bahasa di atas tidak semua masih bertahan, sebagian ada yang masih ada tetapi tidak banyak dipergunakan. Ketiga bahasa yang pertama telah lenyap, demikian pula sebagian dari bahasa-bahasa Yaman Lama. Sedangkan tiga yang terakhir masih ada, tapi bahasa Arab adalah yang paling menonjol dan paling luas tersiar dan tersebar. Meskipun sudah tergolong tua dari masa penggunaannya akan tetapi bahasa Arab masih tetap aktif digunakan oleh bukan saja orang Arab akan tetapi di luar kalangan bangsa Arab itu sendiri.

Sejak zaman lampau hingga sekarang, bahasa Arab merupakan bahasa yang hidup dan aktif digunakan. Dari empat bahasa yang terhitung tua yaitu bahasa Sansekerta, Yunani, Romawi, dan Latin hanya bahasa Arab yang masih tetap digunakan, sementara bahasa lainnya hampir punah dari penggunaannya. Realitas inilah yang menjadi salah satu penyebab keunggulan bahasa Arab dari bahasa lainnya. Karena itu pada tahun 1974, PBB menjadikan bahasa Arab sebagai bahasa internasional ke-6, tercatat sekitar 246 juta orang yang menggunakan bahasa Arab. Selain penggunaan bahasa Arab sendiri banyak berasal di Timur Tengah seperti Kuwait, Arab Saudi, Irak, dan

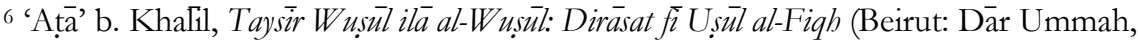
2000), 115.

7 M.H Bakalla, Arabic Culture (London: Kegan Paul,1984), 4.

8 Mun'im Sirry, Kontroversi Islam Awal: Antara Maz̧ab Tradisionalis dan Revisionis (Bandung: Mizan Pustaka, 2015), 32.
} 
Mesir, bahasa ini pun digunakan oleh non-Arab terutama umat Islam karena keterkaitannya dengan kitab suci Alquran.

Bentuk-bentuk kata dalam bahasa Arab mempunyai tașíf (konjungsi), yang amat luas hingga dapat mencapai 3000 bentuk perubahan, yang demikian itu tak terdapat dalam bahasa lain. Para ahli bahasa pernah mengadakan penelitian yang menyebutkan bahwa bahasa Arab memiliki sinonim yang paling banyak dalam penyebutan nama-nama benda. Misalnya untuk seekor unta, orang Arab punya sekitar 800 kata yang identik dengan unta. Untuk kata yang identik dengan anjing ada sekitar 100 kata. Maka tak ada satu pun bahasa di dunia ini yang bisa menyamai bahasa Arab dalam hal kekayaan perbendaharaan kata.

Bahasa Arab digunakan sebagai bahasa Alquran, setelah mengalami proses perjalanan dan melalui tahapan sejarah di era formatif yang panjang. Alquran sendiri telah menyatakan bahwa bahasa yang dipergunakan dalam pewahyuan adalah bahasa Arab (bi lisān 'arabiyy mubin) dengan bahasa Arab yang jelas.

Kefasihan bahasa Quraish ini terutama ditunjang oleh tempat tinggal mereka yang secara geografis berjauhan dengan negara-negara bangsa non-Arab dari segala penjuru. Di bawah kefasihan Quraish adalah bahasa kabilah Thaqif, Hudzail, Khuzā‘ah, Bani Kinānah, Ghatafan, Bani Asad dan Bani Tamim, menyusul kemudian kabilah Rabi'ah, Lakhm Juzām, Ghassān, Iyāạ, Qạ̣āáah dan Aram Yaman yang bertetangga dekat dengan Persia, Romawi dan Habashah. ${ }^{10}$

Dari sekian banyak ragam bahasa yang digunakan pada saat itu, bahasa yang terpilih sebagai bahasa resmi Alquran adalah bahasa Quraish. Sementara keberadaan suku Quraish sangat strategis, hal ini dikarenakan Makkah yang sebagian besar masyarakatnya bersuku Quraish merupakan lalu lintas perdagangan bangsa Arab dan pusat perekonomian masa itu, otomatis banyak mengundang suku-suku lain berdatangan ke daerah ini. Lambat laun banyak orang yang mengenal dan mengerti bahasa ini untuk komunikasi antar mereka. Tanpa disadari bahasa Quraish telah tersebar luas di seluruh jazirah sejak masa pra-Islam. Sehingga mereka menjadikan bahasa Quraish sebagai

9 Ṭaha Muștafa Abū Karishah, "Dawr al-Azhar wa Jami'atih fi Khidmāt al-Lughah al-'Arabijah wa al-Turāth al-Islāmi," dalam Nadwat al-Lughah al-'Arabijab bayn alWá-'، wa al-Ma'mul, Mesir, 2001, 42.

10 Mustafa Șàdiq al-Rafí̄i, Târikeh $\bar{A} d \bar{a} b$ al-'Arabi, vol. 1 (Beirut: Dār al-Kutub al'Ilmìah, t.th.), 252-253. 
lingua franca (bahasa bersama) bagi masyarakat yang multi etnik di tengah-tengah bangsa Arab.

Dalam sejarah kodifikasi Alquran tercatat sahabat 'Uthmān yang telah menetapkan penulisannya dengan bahasa Arab standar. Tujuan dari penetapan ini tergambar dalam suatu riwayat Imam al-Bukhāri tentang kodifikasi wahyu masa 'Uthmān menyebutkan bahwa Alquran ditulis dengan bahasa Arab Quraish yang merupakan bahasa bersama di kalangan suku-suku di Jazirah Arab. Tampilnya bahasa Quraish, sebagai bahasa utama tidak terlepas dari keberadaan suku tersebut yang lebih dominan dalam kancah perdagangan dan posisi strategisnya yang ditempati ka'bah, di mana ka'bah menjadi pusat kegiatan ritual kepercayaan mereka menjelang datangnya Islam.

Rasulullah dilahirkan di kalangan suku Quraish bahkan dari kalangan terpandang yaitu Bani Hashim dan tentunya bahasa keseharian beliau adalah bahasa Arab Quraish. Walaupun pada dasarnya beliau mengusai dialek-dialek lain karena dibesarkan di tengah-tengah Bani Sa'ad yang oleh masyarakat Arab dikenal sebagai suku paling fasih dalam berbahasa.

Bahasa inilah yang kemudian dan sekarang digunakan dalam berbagai tulisan berbahasa Arab, pidato-pidato, siaran-siaran dan jurnalisme. Terpilihnya dialek Qurasih menjadi lingua franca antara berbagai kabilah yang memiliki berbagai dialek lokal menurut beberapa pakar bahasa Arab seperti 'Abd al-Wā $\overline{f i}$ dan Ṭaha Husayn dan Ibn Faris mempunyai alasan strategis yaitu: Pertama, pandangan bahwa di antara berbagai dialek kabilah itu, dialek Quraish adalah yang paling fasih, dominan, dan dipahami oleh berbagai kabilah di seluruh jazirah pada masa pra-Islam. ${ }^{11}$

Kedua, Dialek Quraish mengungguli dialek-dialek lain dan menjadi bahasa sastra lintas kabilah. Karena itu tidak mengherankan jika Alquran diturunkan menggunakan dialek Quraish, disamping Nabi Muhammad yang diutus sebagai rasul juga berasal dari kabilah ini. ${ }^{12}$ Ketiga, Dominasi dialek Quraish terhadap dialek-dialek lain pra-Islam itu karena tempat tinggal kabilah Quraish adalah Makkah, menjadi tempat pelaksanaan ibadah haji, kota dagang dan pusat kesatuan politik yang otonom dari kekuatan-kekuatan lain. ${ }^{13}$

11 Ibn Faris, Fiqh al-Lughāh wa Sunan al-'Arab fĭ kalamihā (Beirut: Mu'assasat Badran, 1963), 52.

12 'Abd al-Wafi, Figh al-Lugah (Mesir: Dār al-Nahḍah, t.th.), 112.

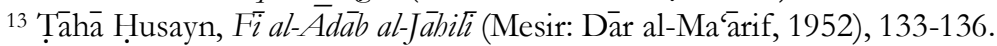


Dari beberapa tinjauan pakar sejarah bahasa tersebut menunjukkan kuatnya alasan terpilihnya dialek Quraish sebagai bahasa agama yang termaktub dalam kitab suci Alquran. Pandangan tersebut juga didasari oleh faktor strategis dalam proses penyeleksiannya yang cukup selektif, sehingga bahasa itu benar-benar dapat mewakili dari keberadaan bahasa yang ada di muka bumi ini.

Kefasihan berbahasa itu terus terpelihara hingga meluasnya ekspansi Islam ke luar jazirah dan masyarakat Arab mulai berinteraksi dengan masyarakat bangsa lain. Dalam proses interaksi dan berbagai transaksi sosial lainnya itu terjadi proses saling mempengaruhi antar bahasa. Masyarakat 'Ajam belajar berbahasa Arab, dan masyarakat Arab mulai mengenal bahasa mereka. Intensitas interaksi tersebut lambat laun mulai berimbas pada penggunaan bahasa Arab yang mulai bercampur dengan beberapa kosakata asing, baik melalui atau tanpa proses arabisasi. ${ }^{14}$

Ketika Nabi Muhammad mendapatkan wahyu dari Allah dalam format bahasa Arab, adalah suatu hal yang sangat wajar melihat latar belakang dan keunggulan bahasanya yang telah dipahami oleh suku dan bahasa lainnya. Justru tidak logis kalau Alquran menggunakan bahasa lain yang tidak dipahami masyarakat Arab. Kenyataan bahwa Alquran diturunkan dalam bahasa Arab hendaknya dijadikan acuan untuk memahami kemukjizatan Alquran sehingga sedikit mungkin dapat menghindar dari kesalahpahaman.

\section{Pembentukan dan Keterkaitan Bahasa Arab dengan Alquran}

Terbentuknya bahasa Alquran ini pun cukup unik dan mempunyai nilai strategis. Keunikan dan nilai strategisnya tergambar dari bagaimana bangsa Arab pra-Islam terdiri dari beberapa kabilah dan memiliki sejumlah ragam dialek bahasa (al-labjät al-'aräbiyah alqadimah) yang berbeda-beda kemudian membentuk satu kesatuan bahasa, dan kemudian dapat mempersatukan keragaman suku dan bahasa kesatuan. Sehingga dapat menyeragamkan perbedaan suku dan bahasa dialek yang diakibatkan karena kondisi-kondisi khusus yang ada di masing-masing wilayah. ${ }^{15}$

Masyarakat Arab pada masa turunnya wahyu adalah masyarakat yang sangat mengagungkan bahasa. Syair-syair yang muncul di

\footnotetext{
14 Umar Faruq, "Telaah Pemikiran Ibn Taymiyah tentang Arabisasi Linguistik dalam Alquran dan Hadis," Mutawatir Jurnal Keilmuan Tafsir Hadith, Vol. 7, No. 1 (2017).

15 Al-Wafi, Al-Lughah wa al-Mujtama'(Jeddah: Sharikat Maktabat Ukaz, 1983), 119.
} 
kalangan mereka selalu membawa pengaruh sosial dan politik pada masa itu. Kemunculan Rasulullah dengan ajaran yang baru dan sangat bertentangan dengan paham yang ada mengundang penentangan yang hebat, bahkan mengancam nyawa. Karen Armstrong memberikan gambaran bahwa penentangan terhadap ajaran Islam mulai menempati titik nadir saat Rasulullah menyerukan ajaran monoteistik, masyarakat Arab tidak pernah terbayang akan konsep ketunggalan Tuhan. Hal ini yang menyebabkan pergolakan politik dan teologis di kalangan Arab, hingga membahayakan nyawa Rasulullah. ${ }^{16}$

Sebagaimana Nabi-nabi lain yang telah terdahulu, setiap nabi dibekali dengan mukjizat yang dapat menaklukkan penentangan kaumnya sehingga mereka mempercayai risalah yang dibawanya. Jika nabi Musa yang berhadapan dengan Fir'aun dan bala tentaranya dibekali dengan mukjizat yang dapat menandingi sihir, maka Rasulullah yang berhadapan dengan masyarakat pengagum keindahan bahasa dibekali kitab suci dengan kualitas bahasa yang mampu menandingi para ahli sastra pada masanya.

Bahasa Alquran baik dalam pemakaian kata maupun penyusunannya, diakui oleh masyarakat Arab sendiri sejak awal mula diturunkan hingga saat ini akan keindahannya. Gaya bahasa yang indah dari Alquran sekaligus menafikan adanya campur tangan manusia seperti dituduhkan oleh pihak yang tidak mengimaninya. Akan tetapi segala dari segala keindahan yang dimiliki oleh kemukjizatan Alquran justru menjadikan dampak positif secara tidak langsung kepada bahasa dan pengucapan Rasulullah. Para pakar bahasa menilai amat sulit bagi seseorang untuk memiliki dua gaya bahasa yang berbeda. Jika anda membandingkan gaya bahasa Alquran dengan gaya bahasa hadis maka anda akan menemukan suatu perbedaan yang menonjol, akan tetapi kemampuan itu hanya dimiliki oleh seorang al-nabi al-ummi yaitu Nabi Muhammad. ${ }^{17}$

Gaya tersebut memiliki relasi (Arab-Alquran) strategis, Alquran menegaskan dalam surah Yūsuf: Innā anzalnāh qur'àn 'arabìyy la'allakum ta'qilun, "Sesungguhnya Aku telah turunkan padanya (Muhammad) Alquran yang berbahasa Arab agar kalian termasuk orang-orang yang berakal." ${ }^{18}$ Dari sini tergambar jelas bahwa ada keterkaitan yang sangat

\footnotetext{
${ }^{16}$ Karen Armstrong, Sejarah Tuban: Kisab 4000 Tabun Pencarian Tuban dalam Agamaagama Manusia, terj. Zaimul Am (Bandung: Mizan Pustaka, 2012), 232.

17 M. Quraish Shihab, Mukjizat al-Qur'an, (Bandung, Penerbit Mizan, 2003), 85-86.

${ }^{18}$ QS. Yüsuf [12]: 12.
} 
erat antara bahasa Arab dan Alquran. Pada ayat lain juga ditegaskan hal serupa. ${ }^{19}$ Dengan adanya penegasan inilah yang menguatkan pijakan para ahli bahasa untuk menyatakan bahwa bahasa Alquran adalah bahasa Arab bukan bahasa 'ajam lainnya.

Bangsa Arab mendapat kehormatan dengan bahasanya yang menjadi bahasa wahyu. Kedatangan Islam dengan Alquran memberikan dorongan yang besar kepada kaum muslimin pada waktu itu untuk belajar bahasa Arab karena kedudukannya sebagai bahasa Alquran. Banyak orang-orang di luar Arab berusaha belajar bahasa Arab agar dapat memahami Islam. Tak dapat dipungkiri bahwa bahasa Arab termasuk salah satu bahasa yang paling banyak digunakan di dunia saat ini. Perluasan bahasa ini didukung oleh kondisi masyarakat Arab itu sendiri yang selalu berpetualang dari satu tempat ke tempat lainnya.

Jika diamati sejarah dari kondisi masyarakat Arab pra-Islam, kebanyakan berprofesi sebagai pedagang, karena kondisi tanah yang gersang dan tandus, yang tidak mungkin bagi mereka untuk bercocok tanam. Sehingga paling cocok sebagai pedagang yang selalu berkeliling mencari dan menawarkan barang dagangannya. Kegiatan ini mendukung interaksi dengan bangsa lain, dan lewat jalur perdagangan ini pula kegiatan dakwah Islam sering mereka lakukan. Sehingga interaksi masyarakat Arab dengan bangsa lain mengakibatkan pengaruh yang luas pada bahasa mereka dan bagi bahasa-bahasa yang mereka lalui. Sehingga ketika wahyu diturunkan kepada Rasulullah beberapa kata asing sudah masuk ke dalam bahasa Arab. Kata yang masuk ke dalam bahasa komunikasi mereka kadang dipakai apa adanya kadang mereka carikan padanan katanya, inilah yang mereka sebut al-tarkīb yaitu upaya mewujudkan kata dalam bahasa Arab untuk istilah dan ungkapan dari kata asing yang mereka adopsi. Hal yang sama juga dilakukan oleh bangsa-bangsa lain, dan merupakan gejala wajar dalam dinamika suatu bahasa. Gejala ini tentunya dialami juga oleh dialek Quraish.

\section{Gaya Bahasa Alquran}

Tujuan utama turunnya wahyu dari Allah adalah pemberian informasi, atau sebuah hubungan komunikasi antara dua pihak untuk menyampaikan pesan kepada utusannya baik secara langsung maupun

\footnotetext{
19 Lihat QS. al-Naḥl [16]: 103, al-Shu'ara', [26]: 193-195, al-Ra'd [13]: 37, Fuṣṣilat [41]: 3, al-Shūrā [42]: 7, al-Zukhruf [43]: 3, al-Aḥqâf [46]: 12, Ṭăhā [20]: 113.
} 
samar. ${ }^{20}$ Situasi komunikasi ini dalam konteks wahyu Alquran sangat berbeda dengan situasi komunikasilain: dalam proses berkomunikasi ini pada hakikatnya Allah ingin menunjukkan dirinya eksis, atau untuk menyatakan tentang eksistensi diri. Dua sisi komunikasi yang mendasar dalam proses pewahyuan adalah Allah di satu pihak sebagai pembicara (speaker) dan Rasul yang manusiawi sebagai pendengar (listener) di pihak lain, sementara wahyu itu sendiri adalah sebagai pesan (message). Proses ini memiliki cara-cara tertentu sebagaimana yang diungkap dalam Alquran. ${ }^{21}$ Wahyu yang berbentuk bahasa sebagai salah satu media berkomunikasi merupakan ekspresi dan eksternalisasi diri agar dirinya dipahami dan diterima orang lain, dan sebaliknya, lewat bahasa pula seseorang melakukan identifikasi dan internalisasi nilai-nilai serta informasi yang dijumpai di sekelilingnya. Tidak berlebihan kiranya, ketika Allah memberikan wahyu kepada Nabi Muhammad maka semenjak itu Nabi bertindak sebagai perantara antara Tuhan dan dunia. ${ }^{22}$

Di samping itu, walaupun mempelajari tata bahasa itu penting, tetapi Alquran sebagai bentuk bahasa ucap atau lisan mempunyai teori gramatika (tata bahasa) tersendiri. Tidak cukup hanya dengan sekadar belajar ilmu Naḥw-Ṣaraf (tata bahasa Arab biasa), karena bahasa Alquran memiliki hakikat yang khusus, berbeda dengan bahasa Arab yang biasa diungkapkan. Dengan demikian, untuk memahami ayat-ayat Alquran tidak mungkin hanya berdasarkan pada kaidahkaidah linguistik semata. Sebab itu, sangat realistis bilamana kemudian dikembangkan bahasa metafor dan analogi (majā̌-tashbīb). ${ }^{23}$ Sebab, bahasa metafor dan analogi dapat memberikan jembatan rasio manusia yang serba terbatas dengan dimensi Ilähijah dan metafisik yang tak terbatas.

\section{Bahasa Metafor (Majāz)}

Bahasa metafor atau bahasa simbol adalah perangkat literer yang lazim di kalangan kritikus sastra dan pemikir Muslim klasik. Matafora

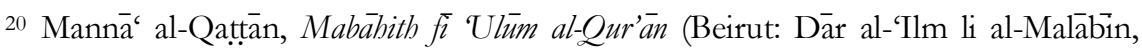
2000), 32.

${ }^{21}$ Deddy Mulyana, Ilmu Komunikasi: suatu Pengantar (Bandung: Remaja Rosdakarya, 2001), 134.

22 Toshihiko Izutsu, Relasi Tuhan dan Manusia: Pendekatan Semantik Terhadap al-Qur'an (Yogyakarta: Tiara Wacana, 1997), 197.

${ }^{23}$ M.S. Kaelan, Filsafat Bahasa: Masalah dan Perkembangannya (Yogyakarta: Paradigma, 1998), 72.
} 
banyak digunakan oleh Alquran untuk menunjukkan keindahan dan gaya bahasa yang sempurna. Metafor dikenal dalam ilmu Balagah dengan istilah majar, tashbīh, atau kināyab: gaya bahasa yang menggunakan perumpamaan atau simbol-simbol. Dengan gaya bahasa ini ayat-ayat dalam Alquran serasa tidak asing dan dekat dengan para pembacanya, tanpa mengurangi makna keindahan sastra yang ada di dalamnya. Gaya seperti ini sudah dikenal sejak lama oleh kalangan sastrawan Arab dan sering dieksploatasikan dalam karya sastra yang diciptakan untuk menghilangkan kegelisahan dan kepenatan hidup guna mencari kebahagiaan dan kesenangan walaupun hanya terjadi dalam dunia imajinasi.

Hakikat Alquran sebagai sarana komunikasi antara Tuhan dengan makhluk-Nya, sedangkan bahasa Arab dalam pengertian umum hanya merupakan sarana komunikasi antara manusia satu dengan yang lainnya. Mengingat hakikat bahasa Alquran mengacu pada dimensi tersebut di atas, maka untuk memahami ayat-ayat Alquran tidak mungkin hanya berdasarkan pada kaidah-kaidah linguistik semata. Sebab itu dalam upaya mengatasi stagnasi bahasa, terutama kaitannya dengan dimensi Ilahiyah, dimensi metafisik, dan dimensi adikodrati, realistis jika kemudian dikembangkan bahasa metafor dan analogi (majaz-tashbihb). Karena bahasa metafor dan analogi dapat memberikan jembatan rasio manusia yang terbatas dengan dimensi Ilahiyah yang serba tidak terbatas. Hal ini berdasarkan pada suatu kenyataan tentang hakikat bahasa sebagai simbol pasti memiliki suatu acuan. Ungkapan metaforis yang disajikan Alquran terkait dengan faktor psikologis dan peradaban umat manusia secara umum. Ia merupakan hasil proses dialektis dan jawaban Muhammad atas konteks yang dihadapi. Dalam konteks tertentu Alquran perlu menyampaikan dengan bahasa metaforis, dan pada konteks yang lain harus diungkapkan dengan bahasa yang tegas dan lugas. Sehingga Alquran didesain dan dikonstruksi sesuai dengan konteksnya. Dengan begitu, pemahaman baru terhadap Alquran bukan berarti mereduksi, tetapi membuktikan sejauh mana Alquran mampu berdialog dengan realitas umat manusia.

Pengungkapan dengan gaya bahasa pada saat Alquran diturunkan memang sangat diperlukan, sebab secara psikologis maupun sosiologis masyarakat Arab sudah memiliki keyakinan yang kuat, berwatak kasar, berpikiran sempit, dan hidup tidak pasti. Selain mengandung misteri dan mitos yang setiap saat akan melahirkan nuansa, imajinasi dan jawaban konseptual dengan mengaitkannya pada konteks sosial dan 
psikologis pembaca, bahasa metaforis juga memiliki kekuatan yang bisa mempertemukan antara ikatan emosional dan pemahaman kognitif sehingga seseorang dimungkinkan untuk mampu melihat dan merasakan sesuatu yang berada jauh di belakang teks. Dan juga diyakini, bahwa bahasa metaforis memiliki kekuatan yang bisa membangkitkan imajinasi kreatif untuk membuka wilayah pemahaman baru yang batas akhirnya belum diketahui.

Konsep majaz, dikembangkan antara lain oleh ahli Alquran dan filologi, yakni Sibawayh (w. 180 H), ia menyatakan bahwa majaz adalah seni bertutur yang memungkinkan terjadinya perluasan makna. Tokoh linguistik lain yang juga memberikan kontribusi terhadap konsep majaz. adalah al-Mubarrad (w. $286 \mathrm{H}$ ), ia mengatakan majaz merupakan seni bertutur dan berfungsi untuk mengalihkan makna dasar yang sebenarnya. Begitu pula dengan Ibn Jinni (w. $392 \mathrm{H}$ ), seorang linguis yang turut menguraikan definisi majaz: Ia mengatakan, majaz sebagai lawan dari haqiqah, dan makna haqiqah adalah makna dari setiap kata yang asli, sedangkan majaz adalah sebaliknya, yaitu setiap kata yang maknanya beralih kepada makna lainnya. Dan tidak ketinggalan, alQađ̣i 'Abd al-Jabbār (w. $417 \mathrm{H}$ ), seorang teolog beraliran Muktazilah mengatakan, majaz adalah peralihan makna dari makna dasar atau leksikal ke makna lainnya yang lebih luas. Konvensi bahasa dan maksud penutur merupakan prasyarat terjadinya ungkapan maja $\bar{i} \dot{ }$, dengan begitu 'Abd al-Jabbār membagi dua model mają, yaitu majā̌ dalam konvensi dan majaz dalam maksud penutur. ${ }^{24}$

Senada dengan pandangan ini seperti apa yang diungkapkan oleh 'Abd al-Qāhir, al-Jurjāni (w. $471 \mathrm{H}$ ) melalui penalaran dua konsep yakni majaz via a vis haqiqah mengatakan sebuah kata yang mengacu kepada makna asal atau makna dasar, tanpa mengundang kemungkinan makna lain disebut dengan haqiqah. Sedangkan majaz adalah ketika seseorang mengalihkan makna dasar ke makna lainnya karena alasan tertentu, atau ia bermaksud melebarkan medan makna dari makna dasarnya. Secara teoritik, menurut al-Jurjāni majāz adalah peralihan makna dari yang leksikal menuju yang literer, atau dari yang denotatif menuju yang konotatif. Secara implisit, definisi di atas mengacu pada pengertian majaz mufrad, yakni majaz dalam kosa kata, sekaligus ia menunjukkan jenis majaz, yang kedua yaitu majaz dalam kalimat. Pembagian ini dilandasi pada pertimbangan bahwa seseorang

${ }^{24}$ Setiawan, Al-Qur'an Kitab, 199. 
bisa merangkai majā baik dalam bentuk kosa kata maupun dalam bentuk kalimat. Dan penggunaan ini sangat bergantung pada konteksnya. ${ }^{25}$

Termasuk katagori ungkapan majaz, yang pernah berkembang di kalangan sarjana muslim klasik adalah tashbihb. Istilah tashbỉh pertama kali dipakai pada era al-Mubarrad dan Ibn al-Mu'taz (w. $296 \mathrm{H}$ ), meskipun kata tersebut juga muncul pada era al-Farrā' dan Abū 'Ubaydah, namun hanya sebatas sebagai tambahan penjelasan kebahasaan dan belum sampai pada pengertian sebagai diskursus ilmu bayan. Al-Jāhiz misalnya, meskipun dalam banyak karya ia tidak menjadikan tashbih sebagai obyek kajiannya, namun ia sudah mengulas dan mempergunakannya sebagai penopang argumentasinya akan keindahan gaya ungkap Alquran. ${ }^{26}$ Al-Mubarrad dalam karyanya yang berjudul, al-Kamill memberikan ulasan tentang tashbih. Uraian alMubarrad dinilai oleh para kritikus sastra kontemporer sebagai sumbangan yang sangat berarti terhadap perkembangan tashbih dalam diskursus retorik Arab. Ia berpendapat, tashbīh merupakan seni bertutur yang paling sering dipakai dalam bahasa Arab. Kajian khusus mengenai tashbīh telah dilakukan oleh Ibn Abi 'Awn (w. $323 \mathrm{H}$ ), di mana ia tidak saja membahas tashbīb secara komprehensif, melainkan juga pelbagai macam syair semenjak era klasik sampai era Abbasiah. Dalam karyanya Al-tashbih $\bar{a}$, ia menempatkan ayat-ayat Alquran sebagai pijakan dan basis keindahan serta kesempurnaan ke-ijaz-an Alquran. Tetapi kajian tashbīh secara spesifik sebagai elemen ilmu bayān dalam kerangka sebagai dogma ke-ijä-an Alquran baru diangkat oleh al-Rummāni (w. 386 H). Dibandingkan para sarjana sebelumnya, alRummāni bukan saja membahas tashbīh pada tataran teoritis tetapi ia sudah masuk bagaimana Alquran bisa dilacak keindahan sastranya melalui tashbìh. Embrio pemikiran tashbīh di atas kemudian disempurnakan oleh 'Abd al-Qāhir al-Jurjāini, di mana ia lebih menjelaskan perbedaan antara tashbijh dan tamthil.

Berkenaan dengan kajian tashbīh maka pada tahapan berikutnya memunculkan tema sentral lainnya, yaitu isti arah. Ia merupakan pengembangan dari tashbih, hanya saja perbedaannya kalau isti arah salah satu saja dari cabang tashbīh yang muncul. Sastrawan Arab

\footnotetext{
25 Ibid., 202.

${ }^{26}$ Fạ̣l Hạan 'Abbās, Al-Balagah: Funūnuhà wa Afnānubā (Oman: Dār al-Furqān, 1987), 18.
} 
pertama kali menggunakan istilah isti 'arah adalah Abü Amr b. al-'Alā', (w. $154 \mathrm{H}$ ), kemudian diikuti oleh Ibn Qutaybah (w. $276 \mathrm{H}$ ), alMubarrad, Tha'lab (w. 291 H), Qadamah (w. 337 H), al-Jurjāni, alRummānì (w. 384 H), Abū Hilāl (w. 395 H), Ibn Rashị (w. 463 H), dan 'Abd al-Qāhir (w. $471 \mathrm{H}$ ), dan disempurnakan sehingga menjadi bagian dari ilmu al-bayān pada masa al-Sakaki (w. $626 \mathrm{H}$ ). ${ }^{27}$ Alquran menggunakan istiárah bukan hanya sekedar sebagai proses peminjaman kata, seperti lazimnya digunakan dalam syair Arab, tetapi juga meminjam persamaan yang bisa dicerna secara nalar, atau sebagai persamaan yang diambil berdasarkan kemiripan akal. Sehingga prinsip peminjaman dalam Alquran ini dimaksudkan untuk menarik perhatian para pendengar dan pembaca Alquran sebagai penerima bahasa.

Selain tashbīh dan isti arah tema lain yang menjadi perbincangan adalah kināyah. Konsep ini telah muncul semenjak era Abū 'Ubaydah, al-Farrāa dan al-Jāhiz. Penggunaan kināyah banyak dilakukan oleh mereka dalam hubungannya dengan ayat-ayat Alquran. Hanya saja konsep yang mereka kembangkan belum ditemukan penjelasan yang mendetail, khususnya terkait dengan kritik sastra Arab. Mereka menggunakan kinayah sebatas sebagai perangkat penjelasan tanpa memasuki kepada kajian yang bersifat teoritis.

Al-Jurjāni yang juga pernah melakukan kajian di mana ia menempatkan kināyah sejajar dengan format ungkapan puitis lainnya, seperti isti ${ }^{\bar{a}}$ ah, tashbīh dan mathăl sebagai elemen pembangun teori konstruksinya. Penjelasan al-Jurjāni ini selaras dengan pembagian mengenai ungkapan, yakni makna dan makna dari makna. Makna adalah isi dari kosa kata yang bisa dipahami seseorang tanpa melalui perantara. Sedangkan makna dari makna adalah makna yang tidak bisa didapatkan langsung dari bunyi sebuah kata, melainkan melalui perangkat, dan perangkat tersebut di antaranya adalah isti'arah, tashbīh , mathäl, dan kinayah.

\section{Keuniversalan Alquran dalam Metafora maknawi}

Dalam Alquran, penggunaan gaya bahasa terkadang tidak selalu bermakna tekstual, namun peralihan dari makna dasar kepada makna tertentu juga bertujuan untuk meluaskan makna. Dengan gaya seperti ini semakin nampak keuniversalan gaya bahasa Alquran itu yang

27 'Abd al-Fattāh Lashin, Al-Bayān fī Ḍaw' al-Asālib al-Qur'àn (Beirut: Dār al-Ma'árif, 1985), 160. 
memukul mundur para pesaingnya dari kalangan sastrawan Arab praIslam. Penggunaan bahasa peralihan dari yang denotatif menuju yang konotatif karena ada alasan-alasan tertentu dapat dilihat pada ayat suci Alquran. Misalnya dalam surah al-Baqarah ayat 19:

"Mereka menyumbat telinganya dengan (anak) jarinya."

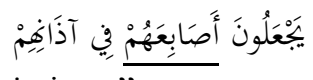

Kata asăbi di atas secara leksikal maknanya adalah jari-jari. Kiranya mustahil bagi orang-orang munafik Mekkah menyumbat telinganya dengan semua jari karena takut bunyi guntur yang mematikan. Maksud așäbi tersebut adalah sebagian dari jari-jari, bukan semuanya. Pemahaman semacam ini berdasarkan konsep teori di atas disebut dengan majar, salah satu alasannya adalah menyampaikan ungkapan dalam bentuk plural, namun yang dimaksudkan hanya sebagian.

Andaikan bisa terjadi menutup telinga dengan semua jarinya pasti dilakukan karena mereka benar-benar mengalami ketakutan yang luar biasa. Situasi ini digambarkan oleh Alquran karena pada awal misi kenabian Muhammad di Mekkah banyak orang yang menyatakan "beriman" kepada Nabi, tetapi mereka masih menyembunyikan kekafiran di dalam hatinya (munafik). Kondisi keyakinan mereka dipaparkan begitu detail dalam Alquran, khususnya dalam surah alBaqarah.

Pada ayat lain juga terdapat proses penghalusan bahasa Alquran yang berimplikasi menjadi sebuah bahasa yang multi tafsir (baca: ambigu), disebabkan oleh faktor bersifat historis maupun bersifat etis. Pengamatan cermat atas ungkapan Alquran akan memunculkan beberapa ayat yang menggunakan bentuk penghalusan bahasa (eufimisme). Misalnya pada al-Nisā' ayat 43:

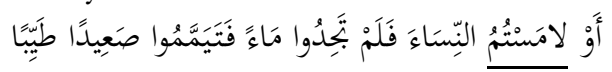

"Atau kamu menyentuh perempuan kemudian kamu tidak mendapat air maka bertayamumlah dengan tanah yang suci."

Secara leksikal kata lamastum berarti saling menyentuh, tetapi jika melihat konteks keseluruhan ayat maka yang dimaksudkan dengan lamastum adalah berhubungan badan karena dalam proses hubungan badan antara suami istri tidak dapat memisahkan adanya sentuhan di antara keduanya yang kemudian melahirkan syahwat. Namun bahasa Alquran dapat menghaluskan ungkapan yang seakan pemahaman pada ayat tersebut menyatakan bahwa dalam proses hubungan suami istri 
ada sentuhan cinta kasih sayang bukan semata-mata karena nafsu syahwat belaka.

Penggunaan kata yang memiliki makna metafora pada ayat di atas menempati kewajaran, sebab secara geografis dan keadaan alam yang ekstrem, kering dan tandus sehingga memaksa orang-orang Arab untuk hidup berpindah-pindah dari satu lembah ke lembah yang lain (nomad) guna memenuhi kebutuhan hidupnya. Kondisi ini seringkali mengilhami para penyair untuk menuangkan karya sastranya dengan bertemakan al-ghazal (romansa). Jadi, perbincangan mengenai kecantikan seorang wanita di kalangan para penyair jahili bukan merupakan sesuatu yang tabu. Bahkan dalam pandangan mereka tema al-ghazal tak ubahnya seperti garam dalam masakan.

Begitu pula dalam ayat Alquran ketika Allah membicarakan kedudukan dan posisi seorang istri di hadapan sang suami ia digambarkan seperti ladang tempat bercocok tanam (harth). Perhatikan ayat berikut:

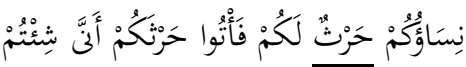

"Isteri-isterimu adalah (seperti) tanah tempat kamu bercocok tanam, maka datangilah tanah tempat bercocok tanam itu bagaimana saja kamu kehendaki."

Secara harfiah merefleksikan kebebasan bagi suami. Namun tidak demikian, sekalipun dalam kenyataannya superioritas laki-laki terhadap perempuan mendominasi saat itu, tetapi Islam telah memberikan aturan yang jelas dan adil. Seorang istri diibaratkan seperti ladang karena pada ayat sebelumnya (ayat 222) membicarakan kondisi perempuan yang menstruasi. Islam memberikan tuntunan bahwa perempuan yang sedang menstruasi tidak boleh diperlakukan seperti dalam keadaan normal. Maka untuk melunakkan dan meluluhkan hati mereka Alquran menggambarkan seorang istri seperti ladang jika ia dalam keadaan suci.

Dalam fenomena masyarakat Arab, ladang memang menjadi simbol ketenangan dan kemakmuran hidup. Peperangan yang terjadi antara kabilah salah satunya disebabkan karena mereka berebut ladang sebagai sumber penghasilan. Supaya mereka tetap mencintai isterinya seperti semula maka ia digambarkan dalam Alquran seperti ladang. Karena dalam tradisi masyarakat Arab pra-Islam apabila istri itu dalam keadaan menstruasi ia ditinggalkan begitu saja, tidak diberi nafkah sehingga statusnya tidak jelas. Tradisi dan budaya yang mendiskreditkan posisi perempuan ini kemudian diperbaiki oleh Islam 
dengan cara yang halus agar kaum perempuan mempunyai hak dan kewajiban yang sama dengan kaum laki-laki.

Dalam pandangan ulama ahli bahasa konsep metafora tidak ada perbedaan yang krusial dengan isti'arah (peminjaman kata). Perbedaan keduanya terletak pada 'aläqah (relasi antara makna dasar dengan makna lain). Jika 'alāqah-nya mushabbahah (ada kesesuaian antara makna dasar dengan makna lain) maka disebut istíarah, dan sebaliknya, jika 'aläqah-nya ghayr mushabbahah (tidak ada kesesuaian) maka disebut majä. ${ }^{28}$

Fenomena Metafora yang sempurna dapat lebih jelas tertera pada ayat berikut:

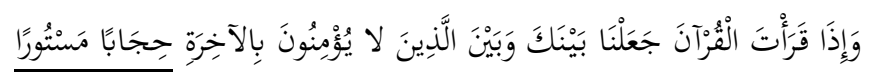

"Dan apabila kamu membaca Alquran niscaya Kami adakan antara kamu dan orang-orang yang tidak beriman kepada kehidupan akhirat, suatu dinding yang tertutup." (QS. 17:45).

Bentuk majāz pada ayat di atas adalah kalimat bijāb masturā (dinding yang tertutup). Menurut mayoritas ahli tafsir maksudnya adalah dinding yang menutup, menggunakan isim fäil pada kata mastürä. Karena kata mastürä bermakna menjadi sasaran yang dikenakan pekerjaan (maf'ú), bukan sebagai pelaku (fa'i $\bar{c}$ ). Jadi, arti yang tepat pada kata mastürä adalah satira. Di sini telah terjadi proses peminjaman makna sätira kepada makna mastūrā yang sudah jelas 'alaqqah-nya adalah ghayr mushabbahah (tidak adanya kesesuaian) antara makna dasar mastūrā (yang ditutup) dengan makna lain (sätira). Pemahaman ini terjadi hanya berdasarkan pada logika dan kebiasaan semata, bukan dari sisi struktur kalimatnya. Dalam kaitan ini al-Jurjāini menegaskan bahwa isti arah sebagai peralihan makna dari kata yang dalam penggunaan bahasa keseharian memiliki makna dasar, atau makna asli, kemudian karena alasan tertentu makna tersebut beralih kepada makna lainnya bahkan terkadang melampaui batas makna leksikalnya. Ia menjelaskan, bahwa isti arah senantiasa mengandung unsur perbandingan.

Berbeda hal dengan ayat dalam QS. Maryam ayat 4, penggunaan isti'arah yang memiliki kesesuaian antara kata dasar yang meminjang degan yang dipinjam:

28 Ahmad al-Hāshimi, Jawāhir al-Balaghah (Beirut: Dār Ihỹā' al-Kutub al-'Arabìyah, 1960), 291. 
"Dan kepalaku telah ditumbuhi uban."

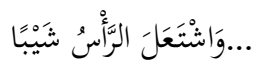

Secara leksikal kata ishta'ala bermakna menyala, al-ra's bermakna kepala, dan shaybä bermakna uban. Namun kurang tepat jika ungkapan tersebut diterjemahkan "dan kepalaku menyala uban." Karena yang lebih pas adalah "dan kepalaku telah ditumbuhi uban." Perpindahan (penggunaan) makna ishta'ala (menyala) kepada nabätà (tumbuh) adalah sesuai (mushabbahab), karena dalam ungkapan itu ada kata alra's. Maksudnya, kata nabätă diserupakan dengan ishta'ala karena begitu banyaknya uban yang tumbuh di kepala. Kemudian kata nabata dibuang dan yang menjadi qairiah (indikator) adalah kata shaybä (uban). Qainah yang dimaksud adalah kata atau keadaan yang tidak memperbolehkan sebuah kata diterjemahkan atau dipahami secara leksikal (haqiqi).

Keindahan dan kesempurnaan ungkapan dalam ayat ini tidak hanya terletak atau berpulang pada peminjaman kata (istíarah) yang digunakan, melainkan juga berpulang pada kekhususan formulasi kalimat dalam ayat itu sendiri. Formulasi yang dimaksud adalah pilihan gaya tutur yang dipakai serta relasi antar struktur bagian kalimat yang satu dengan bagian lainnya. Kata ishta'ala dalam konteks ini mengacu kepada rambut yang memutih, meskipun secara leksikal dianggap mengacu kepada kata al-ra's. Rahasia dari ungkapan ini terletak pada kata ishta'ala yang mengacu kepada rambut yang memutih, seolah rambut terbakar sehingga seluruhnya berubah menjadi warna putih. Makna dasar dari ungkapan ayat di atas adalah "rambut yang memutih," akan tetapi dengan struktur kalimat dalam ayat itu maknanya berkembang menjadi "rambut kepala memutih dengan tidak meninggalkan sisa sehelai rambut pun yang berwarna hitam."

Untuk lebih jelasnya kita dapat memperhatikan firman Allah QS. Ibrähim ayat 1 :

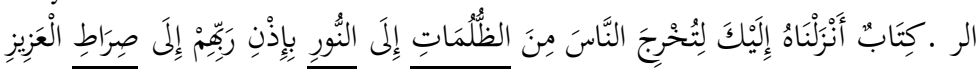

$$
\begin{aligned}
& \text { الحَمِيدِ }
\end{aligned}
$$

"Alif Lam Ra. (ini adalah) Kitab yang Kami turunkan kepadamu supaya kamu mengeluarkan manusia dari gelap gulita kepada cahaya terang benderang dengan izin Tuhan mereka, (yaitu) menuju jalan Tuhan Yang Maha Perkasa lagi Maha Terpuji."

Dalam ayat di atas terdapat tiga kata yang dipinjam yaitu: 


$$
\begin{aligned}
& \text { - } \quad \text { al-zulumāt (gelap gulita), } \\
& \text { - } \quad \text { al-nūr (cahaya), } \\
& \text { al-sirat (jalan). }
\end{aligned}
$$

Kata al-zulumāt dipinjam dari kata al-kufr (kekufuran), asalnya kekufuran diserupakan dengan suasana gelap gulita karena sama-sama tidak ada cahaya atau petunjuk. Kemudian kata al-kufr dibuang dan maksudnya dipinjamkan kepada kata al-zulumāt. Juga kata al-nūr dipinjam dari kata al-imān (keimanan), asalnya keimanan diserupakan dengan cahaya karena sama-sama menerangi kehidupan. Kemudian kata al-iman dibuang dan maksudnya dipinjamkan kepada kata al-nür.

Dan kata al-șirat dipinjam dari kata al-islam (keislaman), asalnya jalan diserupakan dengan Islam karena sama-sama memberikan cara atau petunjuk. Kemudian kata al-islam dibuang dan maksudnya dipinjamkan kepada kata al-sirat. Jadi, dalam memahami ayat tersebut hendaknya kata al-zulumät dipahami sebagai kekufuran, kata al-nür dipahami dengan keimanan, dan kata al-sirät dipahami dengan keislaman.

Secara logika, diturunkannya Alquran untuk manusia bukan karena mereka supaya keluar dari suasana gelap gulita menuju cahaya terang benderang untuk memperoleh jalan. Tapi Alquran adalah wahyu sebagai pedoman hidup manusia, ia diturunkan oleh Allah agar manusia bisa keluar dari kekufuran menuju keimanan dengan aturan yang juga dapat dipahami sebagai petunjuk yang kepada siapa saja bisa Allah berikan sesuai yang dikehendaki untuk menyelamatkan meraka. Bahkan Nabi Muhammad sendiri tidak memiliki kuasa untuk memberikan hidayah kepada orang yang dikasihi dan disayangi yaitu paman yang selalu melindungi perjuangan dakwah Nabi Muhammad, akan tetapi hidayah itu adalah hak tunggal Allah.

Dari bentuk metafora makna yang terdapat pada contoh ayat Alquran, dengan berbagai bentuk: perluasan, penghalusan dan peminjaman makna, telah mentransformasi makna haqiqi kepada konsep yang menurut linguistis seperti Ali al-Harb, M. Abduh, dan Arkoun melahirkan suatu pemahaman universal dan komprehensif dalam memandang suatu permasalahan. Dan dengan gaya metafora ini disamping memberikan perluasan makna, juga akan menambah keindahan bahasa penuturan yang sampai kepada kesempurnaan gaya sastra. 


\section{Kesimpulan}

Ekspresi gaya ungkap gagasan Alquran sebagaimana telah dikaji di atas tidak hanya mempengaruhi daya kognitif pembaca, ia tidak abai pada aspek sastrawi yang menimbulkan efek magis sastrawi. Dengan demikian, Alquran sebagai pusat peradaban Islam tetap menyiratkan sisi keindahan. Antara lain: Gaya bahasa Metafora maknawi menunjukkan akan keluasan makna dan gagasan pada ayat yang tidak dapat ditinjau dari satu sudut pemahaman tekstual semata, akan tetapi juga harus dipahami secara komprehensif untuk dapat memahami ayat lebih utuh pada pemahaman yang dimaksud.

Keindahan dan keluasan makna mengisyaratkan bahwa Alquran sangat peduli akan keindahan bahasa penuturan yang tidak hanya sekedar penghias kata akan tetapi juga mempunyai keluasan pada gagasan dan ide pemikiran. Dalam perkembangan keilmuan, khususnya ilmu kebahasaan, format metafora yang terdapat dalam Alquran dapat dijadikan sebagai rujukan akan kekayaan makna kata yang didukung dengan gagasan tertentu, dan inilah yang menunjukkan keunivesalan Alquran sebagai wahyu.

\section{Daftar Pustaka}

'Abbās, Faḍl Hasan. Al-Balagah: Funūnuhā wa Afnānubā. Oman: Dār alFurqān, 1987.

Armstrong, Karen. Sejarah Tuban: Kisah 4000 Tabun Pencarian Tuban dalam Agama-agama Manusia. Diterjemahkan oleh Zaimul Am. Bandung: Mizan Pustaka, 2012.

Bakalla, M.H. Arabic Culture. London: Kegan Paul,1984.

Färis (Ibn). Fiqh al-Lugāh wa Sunan al-'Arab fì kalamihäa . Beirut: Mu'assasat Badran, 1963.

Faruq, Umar. "Telaah Pemikiran Ibn Taymiyah tentang Arabisasi Linguistik dalam Alquran dan Hadis." Mutawatir Jurnal Keilmuan Tafsir Hadith, Vol. 7, No. 1 (2017).

Ghulayayn (al), Mustafa. Jami $\bar{i}$ al-Durus al-Arabijah. Beirūt: alMaktabah al-'Așriyah li al-Tibā'ah wa al-Tawzi', 1989.

Harb, 'Ali. Al-Ta'wìl wa al-Haqiqah. Beirut: Dār al-Tanwir, 1995.

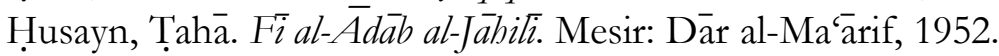

Hāshimi (al), Aḥmad. Jawāhir al-Balāghah. Mesir: Dār Ihyāà al-Kutub al'Arabiyah, 1960.

Kaelan, M.S. Filsafat Bahasa: Masalab dan Perkembangannya. Yogyakarta: Paradigma, 1998. 
Karishah, Ṭaha Muștafa Abū. "Dawr al-Azhar wa Jami'atih $\overline{\mathrm{fi}}$ Khidmāt al-Lughah al-'Arabiyah wa al-Turāth al-Islami,", dalam Nadwat al-Lughah al-'Arabìyah bayn al-Wäqi' wa al-Ma'mūl, Mesir, 2001.

Khaldūn (ibn), Abū Zayd 'Abd al-Raḥmān b. Muhammad. Terjemah Muqoddimah Ibnu Kholdun. Diterjemahkan oleh Ahmadie Thoha. Jakarta: Pustaka Firdaus, 1986.

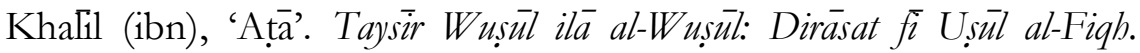
Beirut: Dār Ummah, 2000.

Lashin, 'Abd al-Fattāh. Al-Bayān fì Daw' al-Asālib al-Qur'ān. Beirut: Dār al-Ma‘̄arif, 1985.

Mulyana, Deddy. Ilmu Komunikasi: suatu Pengantar. Bandung: Remaja Rosdakarya, 2001.

Poerwadarminta, WJS. Kamus Umum Bahasa Indonesia. Jakarta: Balai Pustaka, 1991.

Qatțān (al), Mannā'. Mabāhith fì 'Ulüm al-Qur'àn. Beirut: Dār al-'ilm li al-Malābin, 2000.

Rafi'̄i (al), Musțafa Șadiq. Târikeh Ádāb al-'Arabì. Beirut: Dār al-Kutub al-'Ilmiyah, t.th.

Setiawan, M. Nur Kholis. Al-Qur'an Kitab Sastra Terbesar. Yogyakarta: eLSAQ Press, 2005.

Shihab, M. Quraish. Mukjizat al-Qur'an. Bandung, Penerbit Mizan, 2003.

Sirry, Mun'im. Kontroversi Islam Awal: Antara Mą̧ab Tradisionalis dan Revisionis. Bandung: Mizan Pustaka, 2015.

Wāầ (al), 'Ali 'Abd al-Waḥid. Fiqh al-Lugah. Mesir: Dār al-Nahḍah, tt. - 'Ilm al-Lugah. Kairo: Maktabah Nabdah Miș bi al-Fajalah, 1962.

Al-Lughah wa al-Mujtama: Jeddah: Sharikat Maktabat Ukaz, 1983. 